Jurnal Keperawatan Silampari

Volume 5, Nomor 1, Desember 2021

e-ISSN: 2581-1975

p-ISSN: 2597-7482

DOI: https://doi.org/10.31539/jks.v5i1.3068

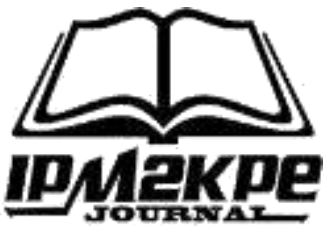

\title{
ANALISIS KEBIJAKAN PEMERINTAH DAERAH DALAM UPAYA PENCEGAHAN PRAKTIK PERNIKAHAN DINI MASA PANDEMI COVID-19
}

\author{
Lisa Pitrianti ${ }^{1}$, Novrikasari $^{2}$, Rizma Adliyah Syakurah ${ }^{3}$ \\ Universitas Sriwijaya ${ }^{1,2,3}$ \\ lisapitrianti@ymail.com ${ }^{1}$
}

\begin{abstract}
ABSTRAK
Penelitian ini bertujuan untuk mengetahui kebijakan pemerintah daerah Kabupaten Kepahiang dalam upaya pencegahan terjadinya praktik pernikahan dini dimasa pandemi COVID 19. Jenis penelitian yang digunakan deskriptif dengan pendekatan kualitatif. Metode penelitian ini menggunakan teknik analisis mendalam (in-depth analysis). Hasil penelitian menunjukkan angka kejadian pernikahan dini di Kabupaten Kepahiang tahun 2019 - September 2021 cenderung meningkat yaitu dari 15,9\% menjadi 44,9\%, terjadi peningkatan sebesar 29\%. Remaja yang melakukan pernikahan di bawah usia 19 tahun diketahui sebagian besar atau sebanyak $73,5 \%$ adalah remaja dengan jenis kelamin perempuan. Simpulan, terdapat beberapa kebijakan yang telah ditetapkan oleh pemerintah daerah Kabupaten Kepahiang antara lain penyelenggaraan kabupaten layak anak, dengan fokus sasaran pada upaya perlindungan anak dan perempuan salah satunya pencegahan pernikahan anak, pemanfaatan teknologi informasi berbasis android dalam upaya perlindungan anak dan perempuan melalui pelaporan via smartphone, upaya pelayanan kesehatan kepada remaja dengan bentuk pelayanan konseling dan berbagai pelayanan yang berhubungan dengan kesehatan remaja, upaya peningkatan peran serta dan pemberdayaan masyarakat dalam rangka peningkatan kesehatan remaja, kebijakan peningkatan pengetahuan remaja khsususnya remaja usia sekolah terkait upaya pencegahan pernikahan dini.
\end{abstract}

Kata Kunci: Kebijakan Pemerintah, Pencegahan, Pernikahan Dini

\section{ABSTRACT}

This study aims to determine the local government's policy of Kepahiang Regency to prevent the practice of early marriage during the COVID-19 pandemic. The type of research used is descriptive with a qualitative approach. This research method uses indepth analysis techniques. The results show that the incidence of early marriage in Kepahiang Regency in 2019-September 2021 tends to increase from 15.9\% to 44.9\%, an increase of $29 \%$. Adolescents who marry under the age of 19 years are mostly, or as much as $73.5 \%$ are adolescents of the female gender. In conclusion, several policies have been set by the local government of Kepahiang Regency, including the implementation of a Child-Friendly Regency, with a target focus on efforts to protect children and women, one of which is the prevention of child marriage, the use of Android-based information technology in efforts to protect children and women through reporting via smartphones. Efforts to provide health services to adolescents in the form of counseling services and various services related to adolescent health, efforts to 
increase community participation and empowerment in improving teenage health, policies to increase adolescent knowledge, especially school-age adolescents, about efforts to prevent early marriage.

Keywords: Government Policy, Prevention, Early Marriage

\section{PENDAHULUAN}

Remaja merupakan masa transisi dari anak menuju masa dewasa. Pada masa ini begitu pesat mengalami pertumbuhan dan perkembangan baik itu fisik maupun mental. Banyak remaja mengalami maturity-gap yaitu perbedaan kematangan secara fisik dan mental. Perbedaan kematangan ini dapat mendorong remaja untuk melakukan hal-hal yang beresiko (Aprianti et al., 2018).

Berdasarkan data penelitian yang dilakukan oleh Pusat Kajian Gender dan seksualitas Universitas Indonesia pada tahun 2015, terungkap angka pernikahan dini di Indonesia menduduki peringkat ke 2 teratas di kawasan Asia Tenggara. Sekitar 2 juta dari 7,3 perempuan Indonesia berusia 15 tahun telah menikah dini dan putus sekolah. Jumlah tersebut diperkirakan akan naik menjadi 3 juta orang pada tahun 2030 mendatang (Dema, 2019).

Tren pernikahan anak perempuan di Indonesia, baik yang melangsungkan perkawinan pertama sebelum usia 18 tahun maupun 15 tahun, menunjukkan penurunan pada periode tahun 2008 sampai 2018, namun penurunannya masih dikategorikan lambat. Masih sekitar 1 dari 9 perempuan berusia 20-24 tahun melangsungkan perkawinan pertama sebelum usia 18 tahun (BPS, 2020).

Dari survei awal yang dilakukan diketahui data jumlah pernikahan dini di Kabupaten Kepahiang pada bulan September 2021, diperoleh telah terjadi peningkatan jumlah pernikahan dini sejak tahun 2019 dimana tercatat sebanyak 45 remaja yang melakukan pernikahan dini, angka ini meningkat pada tahun 2020 dimana tercatat sebanyak 111 remaja atau terjadi peningkatan signifikan sebesar 42,3\%. Pada tahun 2021 sampai dengan bulan September 2021 kembali terjadi peningkatan jumlah remaja yang melakukan pernikahan dini sebanyak 127 kasus atau terjadi peningkatan sebanyak $6,7 \%$, berdasarkan jenis kelamin remaja yang melakukan pernikahan dini dominan terjadi pada remaja perempuan dengan perbandingan laki-laki dan perempuan sebesar 1:3 (Kemenag Kabupaten Kepahiang, 2021).

Bagi remaja dengan adanya pandemi COVID-19 yang menyebabkan pembatasan beraktivitas tentu berdampak pada adanya tekanan mental. Mereka yang biasanya banyak melakukan aktivitas di luar rumah dipaksa harus melakukannya di rumah. Kondisi tersebut berdampak pada masalah emosi dan perilaku atau kesehatan mental mereka. Pada saat pandemi COVID-19 ini, kaum remaja mengalami masa yang sulit. Oleh karena itu, remaja yang mengalami adanya fluktuatif mental akan merefleksikan emosi mereka yang tidak stabil, sehingga mereka akan mudah menderita depresi, emosional (mudah marah), dan hal tersebut berdampak lebih lanjut terhadap adanya kesulitan akademis, penyalahgunaan obat, dan kenakalan remaja (Choirunissa et al., 2020)

Kebijakan pemerintah Kabupaten Kepahiang dalam upaya pencegahan kejadian pernikahan dini dimasa pandemi COVID-19 dilaksanakan oleh beberapa instansi sebagai pemangku kepentingan sesuai dengan tugas dan fungsinya. Dalam penelitian ini dinas dan instansi yang dipilih antara lain; Dinas Pemberdayaan Perempuan, Perlindungan Anak, Pengendalian Penduduk dan Keluarga Berencana (DP3APPKB) 
Kabupaten Kepahiang. Tugas dan fungsi DP3APPKB terkait dengan upaya pencegahan kejadian pernikahan dini merupakan bagian dari tugas Bidang Pemenuhan Hak Anak (PHA), yaitu; 1) Merumuskan kebijakan strategis pengawasan dan pembinaan kegiatan pemenuhan hak anak, perlindungan anak dari kekerasan dan eksploitasi serta perlindungan anak dalam situasi khusus dan darurat; 2) Menyusun bahan pelembagaan Pemenuhan Hak Anak (PHA) pada lembaga pemerintah, non pemerintah dan dunia usaha; 3) Menyusun bahan upaya penguatan dan pengembangan lembaga penyedia layanan peningkatan kualitas hidup anak tingkat daerah kabupaten/kota; 4) Menyusun bahan pencegahan kekerasan terhadap anak yang melibatkan para pihak lingkup daerah kabupaten/kota; 5) Menyusun bahan penyediaan layanan bagi anak yang mengalami kekerasan dan eksploitasi serta memerlukan perlindungan khusus yang memerlukan koordinasi tingkat daerah kabupaten; 6) Menyusun bahan upaya penguatan dan pengembangan lembaga penyedia layanan bagi anak yang mengalami kekerasan dan eksploitas serta memerlukan perlindungan khusus tingkat daerah kabupaten/kota; 7) Menyusun bahan standar operasional prosedur kegiatan pemenuhan hak anak; 8) Menyusun bahan pengumpulan, pengolahan, analisis, mengkaji dan penyajian data dan informasi kegiatan pemenuhan hak anak tingkat daerah kabupaten/kota; 9) Menyusun bahan pencegahan kekerasan terhadap anak yang melibatkan para pihak lingkup daerah kabupaten/kota; 10) Menyusun bahan penyediaan layanan bagi anak yang mengalami kekerasan dan eksploitasi serta memerlukan perlindungan khusus yang memerlukan koordinasi tingkat daerah kabupaten; 11) Menyusun bahan upaya penguatan dan pengembangan lembaga penyedia layanan bagi anak yang mengalami kekerasan dan eksploitas serta memerlukan perlindungan khusus tingkat daerah kabupaten/kota; 11) Menyusun bahan Standar operasional prosedur kegiatan pemenuhan hak anak, 12) Menyusun bahan pengumpulan, pengolahan, analisis, mengkaji dan penyajian data.

Dinas Kesehatan Kabupaten Kepahiang, pelayanan kesehatan bagi remaja merupakan bagian dari Tugas Pokok dan Fungsi (Tupoksi) Dinas Kesehatan khususnya di Bidang Kesehatan Masyarakat, berikut tupoksi dinas kesehatan terkait dengan pengelenggaraan pelayanan kesehatan remaja; 1) Melaksanakan bimbingan teknis dalam pelaksanaan pelayanan anak pra sekolah dan remaja; 2) melaksanakan pembinaan dan bimbingan teknis dalam pelaksanaan pelayanan kegiatan kesehatan peduli remaja di puskesmas; 3) melaksanakan tugas lain sesuai dengan tugas pokok dan bidang tugasnya.

Upaya pencegahan terjadinya praktik pernikahan dini di masa pandemi COVID 19 belum optimalisasi, sehingga penelitian ini menemukan ruang relevansi dan signifikansinya dengan menggali dan menganalisis efektifitas program dan strategi yang telah dilaksanakan oleh pemerintah daerah Kabupaten Kepahiang dalam rangka mencegah terjadinya pernikahan dini dimasa pandemi COVID-19.

\section{METODE PENELITIAN}

Jenis penelitian yang digunakan adalah penelitian deskriptif dengan pendekatan kualitatif. Metode penelitian ini menggunakan teknik analisis mendalam (in-depth analysis), yaitu mengkaji masalah secara khusus perkasus. Pengambilan sampel dalam penelitian ini menggunakan teknik purposive sampling dengan kriteria.

Penelitian ini dilakukan di Pemerintah Daerah Kabupaten Kepahiang dengan melibatkan organisasi perangkat daerah dan instansi terkait dalam pelaksanaan program pencegahan praktik pernikahan dini Informan penelitian merupakan orang-orang yang dijadikan sebagai subjek penelitian dan diharapkan akan memberikan informasi terkait situasi dan kondisi latar belakang penelitian. Dalam penelitian kualitatif informan 
didefinisikan sebagai orang yang memiliki pengetahuan khusus dan pengalaman pribadi tentang situasi yang akan diteliti.

\section{HASIL PENELITIAN}

Tabel. 1

Data Kecamatan

\begin{tabular}{|c|c|c|c|c|}
\hline \multirow{2}{*}{ No } & \multirow{2}{*}{ Kecamatan } & Jumlah & \multicolumn{2}{|c|}{ Ibu Kota Kecamatan } \\
\hline & & Kelurahan & Desa/Kelurahan & \\
\hline 1 & Ujan Mas & 1 & 16 & Ujan Mas Atas \\
\hline 2 & Kepahiang & 7 & 16 & Pasar Ujung \\
\hline 3 & Tebat Karai & 1 & 13 & Penanjung Panjang \\
\hline 4 & Bermani Ulir & 1 & 18 & Keban Agung \\
\hline 5 & Merigi & 1 & 7 & Durian Depun \\
\hline 6 & Kabawetan & 1 & 14 & Tangsi Baru \\
\hline 7 & Seberang Musi & - & 13 & Lubuk Sahung \\
\hline 8 & Muara Kemumu & - & 11 & Batu kalung \\
\hline & Jumlah & 12 & 108 & \\
\hline
\end{tabular}

\section{Angka Kejadian Pernikahan Dini Kabupaten Kepahiang}

Pernikahan dini (early mariage) merupakan suatu pernikahan yang dilakukan oleh seseorang yang memiliki umur yang relatif muda. Batasan umur ini merujuk pada Undang-Undang 16 tahun 2019 tentang perubahan atas UndangUndang Nomor 1 tahun 1974 tentang perkawinan tepatnya pada Pasal 7 ayat (1), yang menyebutkan bahwa perkawinan hanya diizinkan apabila pria dan wanita sudah mencapai umur 19 tahun. Dari hasil penelitian diperoleh data angka kejadian pernikahan dini di Kabupaten Kepahiang :

Tabel. 2

Angka Kejadian Pernikahan Dini

\begin{tabular}{cccc}
\hline No & Tahun & Jumlah & $\%$ \\
\hline 1 & 2019 & 45 & 15,9 \\
2 & 2020 & 111 & 32,9 \\
2 & 2021 & 127 & 44,9 \\
\hline & Total & 283 & \\
\hline
\end{tabular}

Berdasarkan tabel 2 menunjukan jumlah angka kejadian pernikahan dini di Kabupaten Kepahiang tahun 2019 - 2021 (September) menunjukkan adanya kecenderungan peningkatan, dimana pada tahun 2019 jumlah kejadian pernikahan dini sebesar $15,9 \%$ dan meningkat menjadi 44,9\% pada tahun 2021 atau terjadi peningkatan sebesar $29 \%$.

Tabel tersebut juga menunjukan adanya fenomena peningkatan angka kejadian pernikahan dini sebelum terjadinya pandemi COVID-19 dan selama pandemi berlangsung, dimana pada tahun 2019 (sebelum pandemi COVID 19) angka kejadian pernikahan dini sebesar $15,9 \%$ dan meningkat menjadi 32,9\% pada tahun 2020 (awal terjadinya pandemi COVID 19) da selama pandemi COVID 19 berlangsung angka kejadian pernikahan dini terus mengalami peningkatan dimana pada tahun 2021 (September) angka kejadian pernikahan dini di Kabupaten Kepahiang telah mencapai 127 kasus. 
Tabel. 3

Sebaran Angka Kejadian Pernikahan Dini

\begin{tabular}{llccccc}
\hline \multirow{2}{*}{ No } & \multirow{2}{*}{ Kecamatan } & \multicolumn{3}{c}{ Tahun } & \multirow{2}{*}{ Total } & \multirow{2}{*}{$\%$} \\
\cline { 3 - 5 } & & 2019 & 2020 & 2021 & & 70,9 \\
1 & Kepahiang & 14 & 33 & 43 & 90 & 27,6 \\
2 & Tebat Karai & 9 & 12 & 14 & 35 & 16,5 \\
3 & Bermani Ilir & 2 & 6 & 13 & 21 & 10,2 \\
4 & Muara Kemumu & 4 & 2 & 7 & 13 & 10,2 \\
5 & Seberang Musi & 2 & 6 & 5 & 13 & 15,7 \\
6 & Kabawetan & 2 & 9 & 9 & 20 & 51,2 \\
7 & Ujan Mas & 8 & 33 & 24 & 65 & 20,5 \\
8 & Merigi & 4 & 10 & 12 & 26 & \\
\hline
\end{tabular}

Berdasarkan tabel 3 menunjukkan data sebaran angka kejadian pernikahan dini berdasarkan kecamatan di Kabupaten Kepahiang pada tahun 2019-2021 (September). Data di atas menunjukkan bahwa angka kejadian tertinggi berada di wilayah Kecamatan Kepahiang, dimana jumlah kejadian pernikahan dini sebanyak 33,9\%, sedangkan angka kejadian terendah berada di wilayah Kecamatan Seberang Musi dengan persentase kejadian pernikahan dini sebanyak 3,9\%.

Tabel. 4

Jumlah Kejadian Pernikahan Dini

\begin{tabular}{|c|c|c|c|}
\hline No & Jenis Kelamin & Total & $\%$ \\
\hline 1 & Laki-Laki & 75 & 26,5 \\
\hline 2 & Perempuan & 208 & 73,5 \\
\hline & Jumlah & 283 & \\
\hline
\end{tabular}

Berdasarkan tabel 4 menunjukkan bahwa jenis kelamin pada remaja yang melakukan pernikahan di bawah usia 19 tahun diketahui sebagian besar remaja dengan jenis kelamin perempuan $73,5 \%$.

Tabel. 5

Kebijakan Pemerintah Kabupaten Kepahiang dalam Pencegahan Pernikahan dini di Masa Pandemi COVID 19

\begin{tabular}{|c|c|c|c|}
\hline No & Kebijakan & $\begin{array}{l}\text { Isi Kebijakan (Content } \\
\text { Policy) }\end{array}$ & $\begin{array}{c}\text { Pemangku Kepentingan dan Stake } \\
\text { Holder }\end{array}$ \\
\hline 1. & $\begin{array}{l}\text { Peraturan } \\
\text { Daerah } \\
\text { Kabupaten } \\
\text { Kepahiang } \\
\text { Nomor } 4 \text { tahun } \\
2019 \text { tentang } \\
\text { Kepahiang } \\
\text { Kabupaten } \\
\text { Layak Anak }\end{array}$ & $\begin{array}{l}\text { Pedoman } \\
\text { penyelenggaraan } \\
\text { Kabupaten Layak Anak, } \\
\text { focus sasaran upaya } \\
\text { perlindungan anak \& } \\
\text { perempuan salah satunya } \\
\text { pencegahan pernikahan } \\
\text { anak }\end{array}$ & $\begin{array}{l}\text { Dinas Pemberdayaan Perempuan, } \\
\text { Perlindungan Anak, Pengendalian } \\
\text { Penduduk dan Keluarga Berencana } \\
\text { (DP3APPKB) Kabupaten } \\
\text { Kepahiang melalui Gugus Tugas } \\
\text { Kabupaten Layak Anak }\end{array}$ \\
\hline 2. & $\begin{array}{l}\text { Aplikasi E- } \\
\text { PANA } \\
\text { Berbakat }\end{array}$ & $\begin{array}{l}\text { Kebijakan pemanfaatan } \\
\text { teknologi informasi } \\
\text { berbasis android dalam } \\
\text { upaya perlindungan anak } \\
\text { dan perempuan melalui } \\
\text { pelaporan via smartphone }\end{array}$ & $\begin{array}{l}\text { Dinas Pemberdayaan Perempuan, } \\
\text { Perlindungan Anak, Pengendalian } \\
\text { Penduduk dan Keluarga Berencana } \\
\text { (DP3APPKB) Kabupaten } \\
\text { Kepahiang melalui Gugus Tugas } \\
\text { Kabupaten Layak Anak }\end{array}$ \\
\hline
\end{tabular}




\begin{tabular}{|c|c|c|c|}
\hline 3. & $\begin{array}{l}\text { Pelayanan } \\
\text { Kesehatan } \\
\text { Peduli Remaja } \\
\text { (PKPR) }\end{array}$ & $\begin{array}{l}\text { Upaya pelayanan } \\
\text { kesehatan kepada remaja } \\
\text { dengan bentuk pelayanan } \\
\text { konseling dan berbagai } \\
\text { pelayanan yang } \\
\text { berhubungan dengan } \\
\text { kesehatan remaja }\end{array}$ & $\begin{array}{l}\text { Dinas Kesehatan Kabupaten } \\
\text { Kepahiang dan UPT Puskesmas }\end{array}$ \\
\hline 4. & $\begin{array}{l}\text { Posyandu } \\
\text { Remaja dan } \\
\text { Kader } \\
\text { Kesehatan } \\
\text { Remaja }\end{array}$ & $\begin{array}{l}\text { Salah satu upaya } \\
\text { peningkatan peran serta } \\
\text { dan pemberdayaan } \\
\text { masyarakat dalam rangka } \\
\text { peningkatan kesehatan } \\
\text { remaja }\end{array}$ & $\begin{array}{l}\text { Dinas Kesehatan Kabupaten } \\
\text { Kepahiang dan UPT Puskesmas }\end{array}$ \\
\hline 5. & $\begin{array}{l}\text { Bimbingan dan } \\
\text { Sosialisasi } \\
\text { Perkawinan } \\
\text { Remaja Usia } \\
\text { Sekolah }\end{array}$ & $\begin{array}{l}\text { Kebijakan peningkatan } \\
\text { pengetahuan remaja } \\
\text { khsususnya remaja usia } \\
\text { sekolah terkait upaya } \\
\text { pencegahan pernikahan } \\
\text { dini }\end{array}$ & $\begin{array}{l}\text { Kementerian Agama dan Kantor } \\
\text { Urusan Agama (KUA) Kabupaten } \\
\text { Kepahiang }\end{array}$ \\
\hline
\end{tabular}

Fokus penelitian ini adalah untuk mengungkapkan tentang apa yang aan dikumpulkan dalam implementasi kebijakan terkait pencegahan pernikahan dini. Dalam penelitian ini menggunakan operasional model implementasi G. Edward III.

\section{Implementasi Kebijakan}

\section{Kebijakan Kepahiang Kabupaten Layak Anak Deskripsi Kebijakan}

Berdasarkan hasil wawancara yang dilakukan dengan informan kepala bidang pencegahan dan penanganan korban kekerasan, Dinas Pemberdayaan Perempuan, Perlindungan Anak, Pengendalian Penduduk dan Keluarga Berencana (DP3APPKB) Kabupaten Kepahiang, diketahui bahwa kebijakan pemerintah dalam penguatan hukum dan kebijakan dalam perlindungan anak dan perempuan adalah dengan penerbitan Peraturan Daerah Kabupaten Kepahiang Nomor 4 Tahun 2019 tentang Kepahiang Kabupaten Layak Anak.

Penerbitan peraturan daerah ini dilakukan sebelum masa pandemi COVID 19 tepatnya diundangkan pada tanggal 21 Maret 2019, (Lembaran daerah Kabupaten Kepahiang Tahun 2019 Nomor 4). Sedangkan untuk kebijakan penguatan hukum terkait dengan pencegahan pernikahan dini di masa pandemi COVID 19 belum ada, berikut kutipan wawancara dengan informan selaku kepala bidang pencegahan dan penanganan korban kekerasan, Dinas Pemberdayaan Perempuan, Perlindungan Anak, Pengendalian Penduduk dan Keluarga Berencana (DP3APPKB) Kabupaten Kepahiang:

Terkait dengan regulasi yang berhubungan dengan upaya pencegahan pernikahan dini dimasa pandemi Covid-19 di Kabupaten Kepahiang belum ada kita terbitkan, hal ini mengingat pada masa pandemi sesuai dengan kebijakan Bapak Bupati Kepahiang, bahwa Sebagian kegiatan kegiatan di SKPD kita fokuskan ke upaya pengendalian dan penangangan Covid-19 termasuk untuk anggaran (Sumber : Wawancara, 21 Oktober 2021).

Kebijakan kabupaten/kota layak anak ini merupakan tindak lanjut dari kebijakan nasional sebagaimana tertuang dalam Peraturan Presiden Republik Indonesia Nomor 25 tahun 2021 tentang Kebijakan Kabupaten/Kota Layak Anak. Kabupaten/Kota layak 
anak adalah kabupaten/kota dengan system pembangunan yang menjamin pemenuhan hak anak yang dilakukan secara terencana, menyeluruh dan berkelanjutan.

Isi dan substansi dalam peraturan daerah ini menegaskan pertanggung jawaban orang tua, keluarga, masyarakat, pemerintah kabupaten dalam menjamin pertumbuhan dan perkembangan anak, baik fisik, mental, spiritual maupun sosial termasuk didalamnya upaya dalam mencegah terjadinya pernikahan pada usia dini serta menjaga anak untuk tidak terjebak dalam pergaulan bebas, budaya permisivisme, dan terhindar dari NAPZA, HIV dan Aids serta terlindung dari pornografi.

Tujuan dari penerbitan peraturan daerah No 4 Tahun 2019 tentang Kepahiang Kabupaten Layak Anak adalah sebagai acuan dalam peyelenggaraan kabupaten layak anak ini dimaksudkan untuk menjamin terpenuhinya hak anak agar dapat hidup, tumbuh, berkembang dan berpartisipasi secara optimal sesuai dengan harkat martabat kemanusiaan, demi terwujudnya anak yang berkualitas berakhlak mulia, dan sejahtera.

\section{Implementasi Kebijakan \\ Komunikasi}

Komunikasi merupakan suatu proses penyampaian atau menyebarkan informasi. Tujuan dan sasaran kebijakan harus dapat ditransmisikan serta diterima dengan baik kepada kelompok sasaran (target group) agar dapat mengurangi distorsi implementasi.

Transformasi atau penyampaian dari pemrakarsa kegiatan dalam hal ini DP3APPKB Kabupaten Kepahiang kepada pelaksana kegiatan yaitu Gugus Tugas Kabupaten Layak anak sebagai pelaksana implementasi peraturan daerah ini. Dari hasil wawancara yang dilakukan kepada informan kepala bidang pencegahan dan penanganan korban kekerasan, Dinas Pemberdayaan Perempuan, Perlindungan Anak, Pengendalian Penduduk dan Keluarga Berencana (DP3APPKB) Kabupaten Kepahiang diketahui bahwa Gugus Tugas Kabupaten Layak Anak Kabupaten Kepahiang telah dibentuk oleh Bupati Kepahiang.

Kegiatan sosialisasi terkait substansi dan isi peraturan daerah ini telah dilakukan kepada anggota gugus tugas dan diharapkan gugus tugas ini akan melakukan sosialisasi kepada masyarakat terkait dengan kebijakan yang telah diambil oleh Pemerintah Kabupaten Kepahiang tentang kabupaten layak anak dimana substansi kebijakan adalah upaya perlindungan perempuan dan anak termasuk didalamnya upaya pencegahan pernikahan dini.

Dari hasil wawancara antara peneliti dengan informan kepala bidang pencegahan dan penanganan korban kekerasan, Dinas Pemberdayaan Perempuan, Perlindungan Anak, Pengendalian Penduduk dan Keluarga Berencana (DP3APPKB) Kabupaten Kepahiang dapat diketahui bahwa pada masa pandemi COVID 19 sejumlah kegiatan sosialisasi belum dapat dilakukan karena terkendala dengan ketentuan upaya pencegahan dan penanggulangan COVID 19, seperti adanya larangan berkumpul dan social distancing. Selain itu adanya kebijakan refocusing anggaran, dimana adanya pengalihan penggunaan dana pada upaya penanganan dan pengendalian penyebaran COVID 19, hal ini juga berdampak pada pelaksanaan implementasi dari kebijakan ini.

\section{Sumber Daya}

Untuk pencapaian indikator kabupaten layak anak dialokasikan anggaran dari APBD Kabupaten Kepahiang dan sumber dana lainnya sesuai dengan peraturan perundang-undangan yang berlaku dan tidak mengikat sesuai dengan fokus dan program kabupaten layak anak sebagaimana tercantum dalam Rencana Aksi Daerah Kabupaten 
Kepahiang. Untuk menunjang pelaksananan dan implementasi Kabupaten Kepahiang sebagai kabupaten layak anak maka pemerintah Kabupaten Kepahiang melalui DP3APPKB telah menyediakan sarana dan prasarana berupa sekretariat yang diperuntukan untuk gugus tugas KLA.

\section{Disposisi}

Pelaksana kebijkan kabupaten layak anak ini adalah gugus tugas yang dibentuk oleh Bupati Kepahiang, dalam pelaksanaanya gugus tugas KLA ini melakukan bertugas memberikan bimbingan teknis kepada stake holder dan lintas sektor terkait di tingkat Kabupaten, Kecamatan dan Desa/Kelurahan.

Berdasarkan hasil wawancara peneliti dengan informan di DP3APPKB Kabupaten Kepahiang, salah satu kegiatan bimbingan teknis yang diselenggarakan oleh Gugus Tugas KLA dengan bekerjasama dengan fasilitator Nasional Ramah Anak dari Kementerian PPPA berupa kegiatan Bimbingan Teknis Konvensi Hak Anak (KHA).

Dari wawancara kepada kepada salah satu kader PATBM di Kelurahan Pasar Kepahiang, menunjukkan informasi bahwa mereka telah ditunjuk selaku kader PATBM sejak tanggal 25 November 2019 yang lalu, akan tetapi mereka belum mengetahui secara pasti tugas dan fungsi yang dibebankan kepada mereka.

\section{Struktur Birokrasi}

Implementasi kebijakan Kabupaten Layak Anak (KLA) sebagai salah satu kebijakan Pemerintah Kabupaten Kepahiang dalam pemenuhan hak anak yang salah satunya adalah mencegah dari praktik perkawinan anak merupakan bagian tugas dari DP3APPKB, akan tetapi beberapa stakeholder terkait juga memiliki peran dan kewajiban dalam upaya pencegahan anak, tidak hanya lembaga pemerintah namun juga dari organisasi kemasyarakatan, institusi pendidikan, dunia usaha, media massa, untuk itu dibentuk gugus tugas kabupaten layak anak.

\section{PEMBAHASAN}

Mengacu pada pendapat Edward III mengenai kriteria dalam implementasi kebijakan, dikemukakan empat faktor sebagai sumber masalah sekaligus prakondisi bagi keberhasilan proses implementasi, yakni komunikasi, sumber daya, sikap birokrasi atau pelaksana dan struktur organisasi, termasuk tata aliran kerja birokrasi.

Dari hasil observasi peneliti tentang faktor-faktor pendukung implementasi Perda Kabupaten Kepahiang Nomor 4 tahun 2019, bahwa implementasi Perda ini didukung oleh pemerintah daerah karena kebijakan ini merupakan kebijakan publik dengan model sistem, dimana kebijakan ini diformulasi atas dasar prakarsa dari lembaga pemerintah dalam hal ini Dinas Pemberdayaan Perempuan, Perlindungan Anak, Pengendalian Penduduk dan Keluarga Berencana (DP3APPKB) Kabupaten Kepahiang.

Tingkat pernikahan dini di Indonesia sangatlah tinggi, itu dikarenakan didukung oleh keadaan lingkungan yang salah dan bimbingan atau pengetahuan dari orang tua juga salah. Oleh sebab itu perlu suatu bimbingan yang memadai agar mencegah terjaidnya suatu pernikahan dini. Karena banyak dampak negatif dibanding dampak positif dari pernikaha dini. Dibuktikan bahwa jumlah perceraian dan kasus Kekerasan Dalam Rumah Tangga (KDRT) yang meningkat. Anak perempuan adalah yang paling dirugikan dalam pernikahan dini, karena mereka cenderung di nikahkan dengan lakilaki yang sudah dewasa. Banyak hal yang harus ditanggung oleh anak perempuan, itu mengakibatkan kondisi psikologisnya bahkan akan terganggu. Lalu pernikahan dini 
mengakibatkan kenaikan jumlah kelahiran penduduk di Indonesia (Muntamah et al, 2019).

Pernikahan usia anak terjadi disebabkan oleh terhentinya pendidikan, faktor ekonomi, tidak mau mnejadi beban orang tua, kurangnya pengetahuan tentang dampak menikah di usia anak, serta tidak adaya aktifitas lain setelah putus sekolah (Pratiwi et al., 2019). Pengetahuan sangat penting bagi remaja, seperti penelitian yang dilakukan Sartika et al., (2021) menunjukkan bahwa ada perbedaan pengetahuan remaja tentang PKPR sebelum dan setelah penyuluhan. Memberikan pendidikan seksual remaja melalui POSKESJA dapat membantu remaja mengenal kesehatan reproduksi lebih dini sebagai upaya promotif dan prevemtif, sehingga dapat mencegah remaja terjerumus dalam pergaulan bebas dan penyimpangan perilaku kesehatan (Febriawati et al., 2018).

Pernikahan dini merupakan salah satu ancaman bagi pencapaian target Sustainable Development Goals (SDGs) 2030. Untuk mengatasi hal ini dibutuhkan kerjasama dari berbagai pihak untuk mengupayakan pencegahan peningkatan angka kejadian pernikahan dini sebagai upaya preventif untuk menurunkan gangguan dan resiko yang dapat terjadi akibat pernikahan dini (Kurniawati \& Sari, 2020).

Berdasarkan penelitian yang dilakukan oleh Padila et al (2021) didapatkan bahwa ibu usia remaja yang melahirkan di masa pandemi COVID 19 menderita cemas tingkat sedang dan minimnya dukungan keluarga saat melahirkan serta menerima perlakuan dengan kualitas akses pelayanan kesehatan yang kurang.

Berdasarkan penelitian yang dilakukan oleh Muhadara et al., (2016) didapatkan bahwa peran pemerintah yakni KUA Kecematan Polongbangkeng Utara Kabupaten Takalar dalam mengendalikan perkawinan usia dini, diantaranya melakukan koordinasi dengan BKKBN untuk melakukan penyuluhan mengenai dampak dari perkawinan usia dini khususnya mengenai pembatasan usia, program keluarga berencana dan sosialisai kesehatan reproduksi. Sosialisasi setiap minggunya di masyarakat pedalaman untuk tidak menikahkan anak-anak mereka di bawah umur kecuali dalam keadaan terpaksaseperti hamil di luar nikah ataupun faktor lain yang dianggap wajar, mendorong anak-anak mereka untuk mencapai pendidikan yang lebih tinggi serta membuat kebijakan menolak pendaftaran nikah pasangan usia dini sudah berjalan dengan baik.

Upaya pencegahan terjadinya perkawaninan dini sudah dilaksanakan oleh KUA Sukolilo melalui pekasanaan kebijakan pembatasan usia minimal perkawinan dintaranya dengan secara tegas melakukan penolakan terhadap berkas pengajuan perkawinan yang tidak memenuhi syarat minimal perkawinan. Namun upaya tersebut hasilnya kurang signifikan sebab pintu masuk berbagai persoalan seperti manipulasi usia, atau pernikahan dibawah umur secara sikum, berada pada otoritas lembaga lain. Collaborative governance berbasis gender menjadi solusi alternatifnya dengan melibatkan masyarakat, peduma, tokoh agama, ketua RT, kepala desa, kecamatan, KUA, dan pengadilan agama dalam pelaksanaan kebijakan pembatasan usia minimal perkawinan (Dewi et al, 2019).

Berdasarkan hasil penelitian yang dilakukan oleh Dahriah et al., (2020) menyatakan bahwa strategi pemerintah dalam meminimalisi pernikahan dini di kecamtan Maritengngae Kabupaten Sidenreng Rappang belum berjalan secara optimal. Hal tersebut dapat dilihat dari maraknya pernikahan dini yang terjadi dan kurangnya pemahaman dan edikasi yang dilakukan pemerintah kepada masyarakat.

Pemberlakuan kebijakan terhadap pendewasaan usia pernikahan dilandasi adanya berbagiu resiko yang dihadapi masyarakat yang melangsungkan pernikahan usia dini. Kebijakan tersebut diharapkan dapa menekan praktik pernikahan usia dini dalam rangka 
menciptakan generasi berencanan dan peningkatan indeks pembangunan ,asyaraka. Kebijakan tersebut sangat rasional untuk mempersiapkan generasi emas NTB tahun 2025. Upaya pembaharuan kebijakan yang mengatur tentang tentang batas usia perkawinan yang dilakukan Gubernur NTB juga tidak bertentangan dengan ketentuanketentuan yang mengatur tentang kewenangan seseorang pimpinan atau kepala daerah. (Winengan, 2018).

\section{SIMPULAN}

Sebelum terjadi peningkatan sebesar $29 \%$, angka kejadian tertinggi berada di wilayah Kecamatan Kepahiang, dimana jumlah kejadian pernikahan dini sebanyak 33,9\% selama pandemi COVID 19. Terdapat beberapa kebijakan yang telah ditetapkan oleh pemerintah daerah Kabupaten Kepahiang antara lain; penyelenggaraan kabupaten layak anak, dengan fokus sasaran pada upaya perlindungan anak dan perempuan salah satunya pencegahan pernikahan anak, pemanfaatan teknologi informasi berbasis android dalam upaya perlindungan anak dan perempuan melalui pelaporan via smartphone.

Upaya pelayanan kesehatan kepada remaja dengan bentuk pelayanan konseling dan berbagai pelayanan yang berhubungan dengan kesehatan remaja, upaya peningkatan peran serta dan pemberdayaan masyarakat dalam rangka peningkatan kesehatan remaja, Kebijakan peningkatan pengetahuan remaja khsususnya remaja usia sekolah terkait upaya pencegahan pernikahan dini.

\section{SARAN \\ Instasi Pemerintahan}

Untuk melakukan peningkatan fokus intervensi dan pemantapan penerapan program Pendewasaan Usia Perkawanian (PUP) melibatkan instasi lain misalnya Kantor Urusan Agama (KUA), petugas lapangan dan kader di lapangan untuk mengintegrasikan implementasi program PUP ke dalam seluruh program dan rencana kerja lainnya.

\section{Peneliti Selanjutnya}

Melakukan penelitian tentang perbedaan perkawanian usia muda pada wilayahwilayah Kabupaten Kepahiang sehingga nantinya juga akan dapat mengetahui tentang keadaan dan faktor penyebab terjadinya perkawinan usia muda yang paling tinggi frekuensinya. Dengan adanya hal tersebut maka diharapkan pemerintah dapat merumuskan intervensi atau program untuk mengurangi dan menekan frekuensi perkawinan usia muda yang paling tepat dan sesuai dengan keadaan dan karakteristik wilayah kabupaten Kepahiang.

\section{DAFTAR PUSTAKA}

Aprianti, A., Shaluhiyah, Z., \& Suryoputro, A. (2018). Fenomena Pernikahan Dini Membuat Orang Tua dan Remaja Tidak Takut Mengalami Kehamilan Tidak Diinginkan. Jurnal Promosi Kesehatan Indonesia, 13(1), 61. https://doi.org/10.14710/jpki.13.1.61-73

BPS. (2020). Prevention of Child Marriage: A acceleration that Cannot Be Delayed. https://www.unicef.org/indonesia/sites/unicef.org.indonesia/files/202006/Prevention-of-Child-Marriage-Report-2020.pdf

Choirunissa, R., Syamsiah, S., \& Komala, I. R. (2020). Analisis Deteksi Dini Kesehatan jiwa Remaja di Masa Pandemi COVID-19. Repository Universitas Nasional Jakarta, 1-13. http://repository.unas.ac.id/id/eprint/818 
Dahriah, D., Jabbar, A., \& Rusdi, M. (2020). Startegi Pemerintah dalam Meminimalisir Pernikahan Dini di Kecamatan Maritengngae Kabupaten Sidendeng Rappang. Jurnal Ilmiah Pemerintah, 8(3), 163-172. https://doi.org10.51817/prj.v8i3.291

Dema, H. (2019). Peranan Pemerintah dan Partisipasi Masyarakat terhadap Penanggulangan Pernikahan Dini di Kecamatan Pitu Riawa Kabupaten Sidenreng Rappang. $\quad 7, \quad 26-31 . \quad$ https://ejurnal.nobel.ac.id/index.php/akmen/article/view/191

Dewi, S. M,. Rahayu, R., Kismartini, K. Yuniningsih, T. (2019). Pencegahan Perkawinan Dini dan Sirri Melalui Collaborative Governance Berbasis Gender I Kabupaten Pati. Jurnal Studi Gender, 12(2), 519-541. http://doi.org/10.21043/palastren.v12i2.6357

Febriawati, H., Padila, \& Anita, B. (2018). Pendidikan Seksual Remaja Melalui Poskesja. Jurnal Pengabdian Masyarakat Bumi Raflesia, 1(1), 45-54. https://doi.org/10.36085/jpmbr.v1i1.193

Kurniawati, N., \& Sari, K. I. P. (2020). Determinan Faktor Pemicu Terjadinya Pernikahan Dini Pada Usia Remaja. Jurnal Keperawatan, 13(1), 12. Http://ejournal.lppmdianhusada.ac.id/index.php/jk/article/view/74

Muhadara, I., Parawangi, A., \& Malik, I. (2016). Peran Pemerintah Daerah dalam Pengendalian Perkawinan Usia Dini di Kecamatan Polongbangkeng Utara Kabupaten Takalar. Jurnal Adinistrasi Publik, 2(3), 284-300. https://doi.org/10.26618/kjap.v2i3.884

Muntamah, A. L., Laatifiani, D., \& Arifin, R. (2019). Pernikahan Dini di Indonesia: Faktor dan Peran Pemerintah (Perspektif Penegakan dan Perlindungan Hukum Bagi Anak). Widya Yuridika, 2(1), 1. DOI: 10.31328/wy.v2i1.823

Padila, P., Panzilion, P., Andri, J., Nurhayati, N., \& Harsismanto, J. (2021). Pengalaman Ibu Usia Remaja Melahirkan Anak di Masa Pandemi COVID-19. Journal of Telenursing (JOTING), 3(1),

63-72. https://doi.org/https://doi.org/10.31539/joting.v3i1.2075

Pratiwi, B., Anggraini, W., Padila, P., Nopiawati, N., \& Yandrizal, Y. (2019). Analisis Pernikahan Usia Dini di Kabupaten Bengkulu Tengah Tahun 2017. Jurnal Kesmas Asclepius, 1(1), 14-24. https://doi.org/10.31539/jka.V1i1.575

Sartika, A., Oktarianita, O., \& Padila, P. (2021). Penyuluhan terhadap Pengetahuan Remaja tentang PKPR. Journal Of Telenursing (JOTING), 3(1), 171-176. https://doi.org/10.1539/joting.v3i1.2192

Winengen, W. (2018). Politik Hukum Keluarga Islam di Aras Lokal : Analisis terhadap Kebijakan Pendewasaan Usia Pernikahan di Nusa Tenggara Barat. Al-Ahwal: Jurnal Hukum Keluarga Islam, 11(1), 1-12. http://ejournal.uinsuka.ac.id/syariah/Ahwal/article/view/1562/1348 